\title{
УДК 528.92
}

\section{Б. ЧЕТВЕРІКОВ, М. ПРОЦИК}

Кафедра фотограмметрії та геоінформатики, Національний університет “Львівська політехніка”, вул. С. Бандери, 12, Львів, 79013, Україна, тел. +38(063)1671585, e-mail: chetverikov@email.ua

\section{МЕТОДИКА СТВОРЕННЯ ГІС КОНЦЕНТРАЦІЙНИХ ТАБОРІВ НАЦИСТСЬКОЇ НІМЕЧЧИНИ ПЕРІОДУ 1941-1944 pp.}

Мета. Мета роботи - запропонувати методику створення геоінформаційної системи концентраційних таборів нацистської Німеччини в Свропі 1941-1944 pp. Спроєктована ГІС містить полігональні об’ єкти меж концтаборів та атрибутивну інформацію: назву концтабору, країну, тип табору, час існування, кількість в'язнів та кількість знищених людей, коротку історичну довідку. Методика. Найбільшою проблемою досліджень був пошук архівних схем і планів концентраційних таборів. Пізніше ці матеріали проходили геометричну корекцію та “підв' язувались” до сервісу Bing, гібрид (поєднання сервісів Bing-космознімки і Bing-карти) якої використано як картоснову для ГІС. Векторизацію меж об'єктів, для яких вдалось знайти схеми і плани, здійснено за цими матеріалами. Для решти об’єктів межі визначали або за наявністю історичних меж на місцевості (облаштовані меморіальні комплекси на кшталт концтабору Аушвіц), або за архівними описовими матеріалами. Друга частина виконання завдання передбачала створення і наповнення бази даних до векторизованих графічних об’єктів. База даних містила поля символьного і числового типу і складалася із семи стовпців. У перших шести наводили коротку інформацію про назву, розташування об’єкта та кількість знищених людей і тих, які міг вмістити концтабір. Останній стовпець містив коротку історичну довідку про концтабір, отриману у вигляді вебсторінки з мережі інтернет і поєднану 3 атрибутивною базою даних за допомогою гіперпосилання. Результати. В результаті проведених досліджень отримано 83 полігональні об'єкти меж концентраційних таборів із 15 країн Європи, максимально наближені до реальних. Для цих об'єктів створено базу атрибутивних даних, яка складається із семи стовпців, об'єкти мають гіперпосилання на інформаційні сторінки з глобальної мережі інтернет. Наукова новизна. За запропонованою технологічною схемою поєднано в одній базі геопросторових даних 43 архівні схеми та плани концентраційних таборів часів Другої світової війни, попередньо прив'язані до картографічного онлайн-сервісу. Практична цінність. Отриману ГІС нацистських концентраційних таборів часів Другої світової війни можуть використовувати щонайменше спеціалісти, які займаються діяльністю історичного спрямування, та відділи охорони культурної спадщини України. Цю ГІС можна доповнити за потреби іншими об'єктами, адже дослідженням охоплені лише 83 найвідоміші табори, а їх загалом 1634.

Ключові слова: концентраційний табір; історична ГІС; класифікація таборів; картографічний онлайн-ресурс; атрибутивна база даних.

\section{Вступ}

За даними звіту 1967 р. Федерального міністерства внутрішніх справ Німеччини, налічувалося 1634 концентраційні табори та їх підрозділи на захоплених нацистами територіях. Однак за матеріалами Єврейської віртуальної бібліотеки налічується близько 15000 концтаборів і їх підрозділів, створених на окупованих територіях. Згодом більшість 3 них зруйнували самі нацисти. [https://www.jewishvirtuallibrary.org/full-listing-ofconcentration-camps]. Для таборів пристосовували випадкові приміщення або майданчики просто неба, огороджені кількома рядами колючого дроту зі сторожовими вишками, харчування було жахливим, умови утримання нестерпними. Розглянемо класифікацію таборів, які облаштовували нацисти [http://territoryterror. org.ua/uk/projects/prisons/nazi/].

Кониентраційний табір - місце запобіжного ув'язнення людей із політичних, національних та релігійних мотивів. Рішення про ув'язнення приймала державна таємна поліція - гестапо без слідства й суду. У такому таборі в'язнів утримували без встановлення терміну ув'язнення, в умовах особливо суворого режиму (ізоляції).

Виправно-трудовий табір - місце ув'язнення громадян на визначений термін (від 21 до 56 днів, 3 можливістю продовження) за ухилення від трудової повинності, трудові порушення, з подальшим скеруванням на попереднє місце роботи або до концтабору.

Гетто - частина території населеного пункту, виділена для примусового утримання осіб єврейської національності з метою їх ізоляції, а відтак знищення. Існували відкриті та закриті гетто. Майже всі відкриті гетто перед ліквідацією перетворили на закриті із суворою ізоляцією. Протягом війни та під час ліквідації гетто єврейське населення знищували або відправляли до концентраційних таборів.

Табір примусової праці для євреїв - місце ув'язнення осіб єврейської національності, перетворений з гетто 
або новоутворений, куди завозили працездатних євреїв з гетто і використовували для тяжких робіт.

Гестапівська тюрма - місце запобіжного ув'язнення та утримання з політичних мотивів із застосуванням до ув'язнених насильницьких дій виняткової жорстокості, зокрема катувань і вбивств.

Пересильний табір - збірний пункт для відправлення ув'язнених на примусову працю до Третього Рейху.

Трудовий табір - місце для ізоляції населення, змушеного працювати на підприємствах, будівельних роботах тощо.

Шталаг - стаціонарний табір для військовополонених рядового та сержантського складу.

Дулаг - збірний та пересильний пункт для військовополонених та інтернованих цивільних громадян.

Офлаг - стаціонарний табір для військовополонених офіцерів.

3 розвитком цифрових технологій створено чимало геоінформаційних систем історичних подій для збереження та впорядкування інформації про них. Серед інших - і ГІС подій Другої світової війни.

Зокрема, відома ГІС концентраційних таборів Голокосту, створена на основі сервісу ArcGIS on-line [https://www.arcgis.com/home/item.html?id=eb6a158647 ec48be8fe3e628f95dddbc]. Недолік цієї системи доволі незначне інформаційне наповнення (вказано тільки кількісні показники ув'язнених і знищених людей). Якщо ж говорити про графічну складову, то полігональні об'єкти таборів відображають за допомогою точкових об'єктів, іноді розставлених доволі умовно, що потрапляють на полотна доріг тощо.

Досить грунтовним висвітленням об'єктів концентраційних таборів за допомогою ГІС займаються вчені Стенфордського університету [https://web.stanford.edu/ group/spatialhistory/cgi-bin/site/viz.php?id=379], але i вони не вказують межі об' єктів.

ГІС широко застосовують у різних напрямах історичних досліджень, головною їх умовою $є$ просторова прив' язка [Гришин, 2017].

Найпершою великомасштабною ГІС є національна ГIC Великобританії (GBHGIS), яку почали розробляти в 1994 р. GBHGIS містить понад 48 тисяч встановлених і локалізованих одиниць різних рівнів: міст, сільських і міських районів, округів, церковних парафій [Gregory, Southall, 2005]. Реалізація проєкту передбачала встановлення чітких меж і уявлень щодо істоpiї населення на підставі даних переписів за столітню історію [http://www.port.ac.uk/research/gbhgis/ abouttheproject]. Ядром ГІС-проєкту є база даних картографічних джерел. Для HGIS Великобританії оцифровано і прив'язано до сітки британського національного стандартного відображення всі межі
1840-1974 pp. ГІС влаштована так, що за запитом користувача відображає кордони на конкретну дату. GBHGIS розміщена у відкритому доступі. Інтерфейс ГIC дуже зручний: містить загальну інформацію, опис ГІС, джерел, використаних для їі створення. Розподіл за темами дає змогу вибрати потрібну базу даних $\mathrm{i}$ переглядати іiї окремо.

Американська історична ГIC (NHGIS) - проєкт, який фінансує Національний науковий фонд, охоплює період 1790-2011 рр. ГІС містить кордони штатів i округів, дані в межах ділянок перепису на всіх географічних рівнях [https://www. nhgis.org/].

Національний Німецький ГIC-проєкт (HGIS Germany) охоплює держави Німецького союзу 1820-1914 pp., територіально-адміністративні кордони Німеччини 1815-1939 pp. і містить відомості про населення, економіку та династичні зв'язки близько 50 держав Німецького союзу [Kunz, Boehler, 2005].

Проєкт створення Китайської національної ГІС (CHGIS) започатковано в 2001 р., він розпочався зі створення бази даних про населення та історичні адміністративні одиниці за тривалий період китайської історії (221 р. до н. е. - 1911 pp.) [http://www.fas. harvard.edu/ chgis, Bol, Ge, 2005]. CHGIS містить дані про більш ніж 1600 графств, сотні тисяч міст, декілька мільйонів сільських населених пунктів за дві тисячі років. Для доступу ширшої аудиторії записи в CHGIS подані англійською та китайською мовами і доступні онлайн.

Історична ГІС Нідерландів (HisGIS Netherlands) [http://www.hisgis.nl] основана на результатах попередніх досліджень [Boonstra, 1994, Schreven, Boonstra, Doorn, 2005] i охоплює 1811-1990 pp. й адміністративно-територіальну структуру, що склалася у цей період: кордони муніципалітетів і економіко-географічні кордони. Базовий шар представлений архівними картами земельного кадастру, на які нанесено шари, що містять дані про власника, його зайнятість, розміри земельної ділянки, iї кордони i точне місцезнаходження.

Бельгійський проєкт LOKSTAT (“Бельгійське суспільство в історичній статистиці”) відображає дані перепису бельгійського населення на найнижчому територіальному рівні - рівні муніципалітетів за 18001970 pp. Проєкт відображає дані про населення, зокрема про зайнятість. Зручний інтерфейс дає змогу користувачеві самостійно створити карту, вибираючи потрібну йому інформацію, а саме про територію, сферу діяльності, населення за гендерною ознакою [http://cartogis.ugent.be/lokstat].

Підсумовуючи все вищесказане, можна зробити висновок, що ГІС стала невід'ємною частиною історичної картографії та зручним сервісом для поєднання 
архівних і сучасних матеріалів. Якщо ж говорити про ГІС нацистських концентраційних таборів, то необхідно зазначити, що жодна зі створених систем досі не містить адекватних меж історичних об'єктів.

\section{Мета}

Мета роботи - запропонувати методику створення геоінформаційної системи концентраційних таборів нацистської Німеччини в Європі 1941-1944 pp. і за розробленою технологічною схемою створити графічно-атрибутивну структуру ГІС.

\section{Методика}

Для реалізації поставленого завдання ми використали такі вхідні дані:

- 43 архівні схеми і плани концентраційних таборів (схему концтабору Бухенвальд подано на рис. 1);

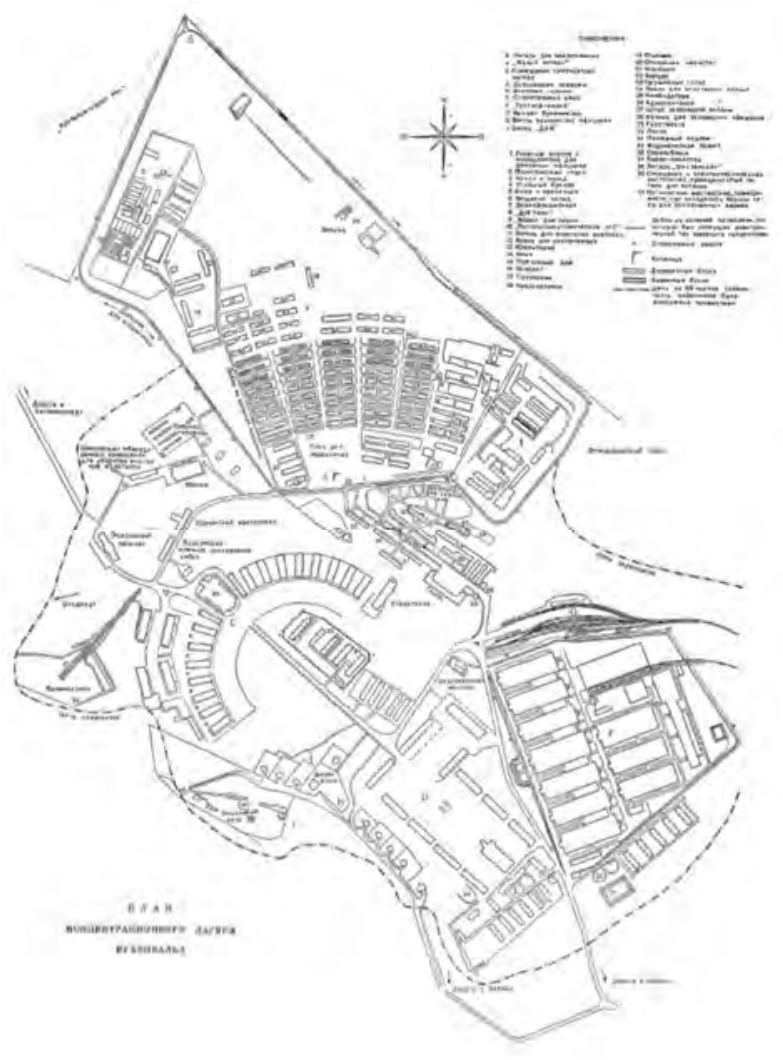

Рис. 1. Схема конщтабору Бухенвальд

- перелік найвідоміших нацистських концентраційних таборів;

- гібридна онлайн-карта сервісу Bing;

- вебсторінки 3 історичною довідкою про концентраційні табори;

- текстова довідкова інформація про розташування таборів.
Щоб систематизувати наші дослідження, запропоновано технологічну схему створення ГІС концентраційних таборів (рис. 2).

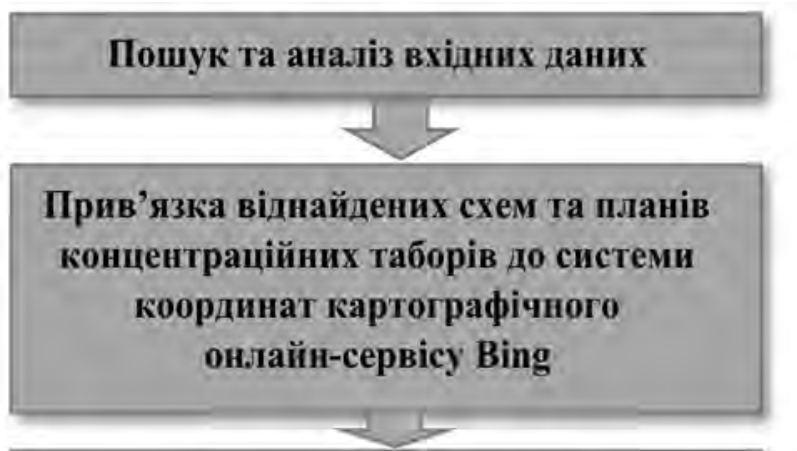

\section{Векторизація території концентраційних таборів}

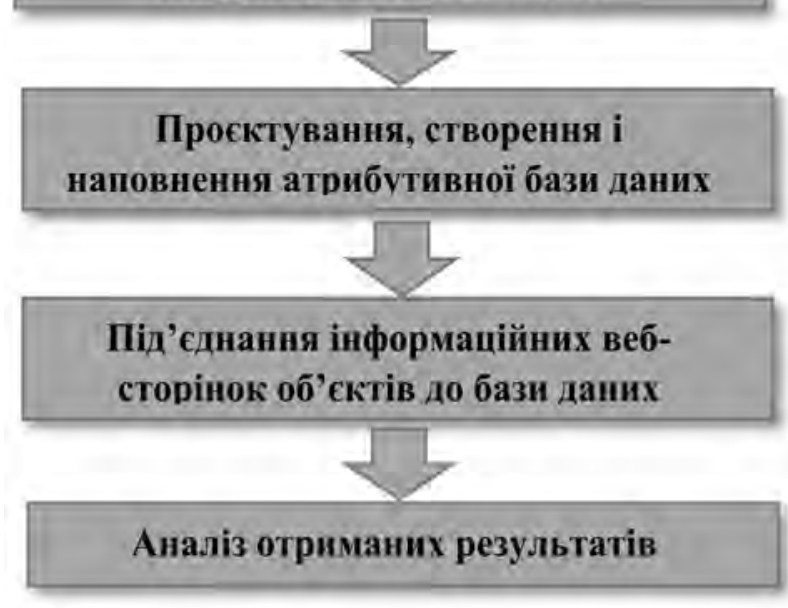

Рис. 2. Технологічна схема створення ГІС кониентраиійних таборів

Прив'язку віднайдених схем і планів концентраційних таборів виконано за різною кількістю опорних точок, від 7 до 9, залежно від ситуації кожного об'єкта. Проєкцію вибрано аналогічно до картографічного сервісу Bing, а саме Popular visualization WGS84, щоб векторизована інформація узгоджувалась із картоюосновою. Максимальна похибка прив'язки становила 11 метрів на місцевості. Нас це задовольнило, оскільки графічний матеріал був переважно схематичний і перед нами не ставили завдання надточного нанесення об'єктів, а лише максимального наближення до реальної картини.

Відповідно векторизацію меж об'єктів для 43 концтаборів здійснено за графічними матеріалами, для 26 об'єктів - за межами, що збереглися, а для 14 - за описовою інформацією щодо приблизних меж, оскільки об'єкти фактично не збереглися або територія таборів забудована після війни. 
Для систематизації інформації класифіковано опрацьовані табори:

- трудові табори;

- $\quad$ табори смерті;

- $\quad$ концентраційні табори;

- пересильні табори;

- гетто.

Структура створеної бази даних об'єктів була такою:

- назва концтабору (символьний формат даних, відповідає назві табору);

- $\quad$ країна (символьний формат даних, відповідає країні, на території якої існував табір);

- $\quad$ тип табору (символьний формат даних, відповідає призначенню табору згідно із класифікацією, наведеною вище);

- кількість загиблих (числовий формат даних, відповідає кількості знищених людей за офіційними історичними джерелами);
- кількість в'язнів (числовий формат даних, відповідає кількості в'язнів, яких міг одночасно утримувати табір, за офіційними історичними джерелами);

- роки існування табору (символьний формат даних, відповідає рокам існування табору);

- історія (символьний формат даних, містить гіперпосилання на зовнішню вебсторінку 3 інформацією про об'єкт із глобальної мережі Інтернет).

За векторизованими графічними об'єктами i наповненням атрибутивної таблиці до них створено відповідну графічно-атрибутивну структуру ГІС, подану на рис. 3. На рис. 3 продемонстровано карту-основу із сервісу Bing на територію Свропи, на якій наведено червоні точки, що відповідають зменшеному зображенню полігональних об'єктів концентраційних таборів. Нижче подано фрагмент атрибутивної таблиці для декількох із 83 внесених об'єктів.

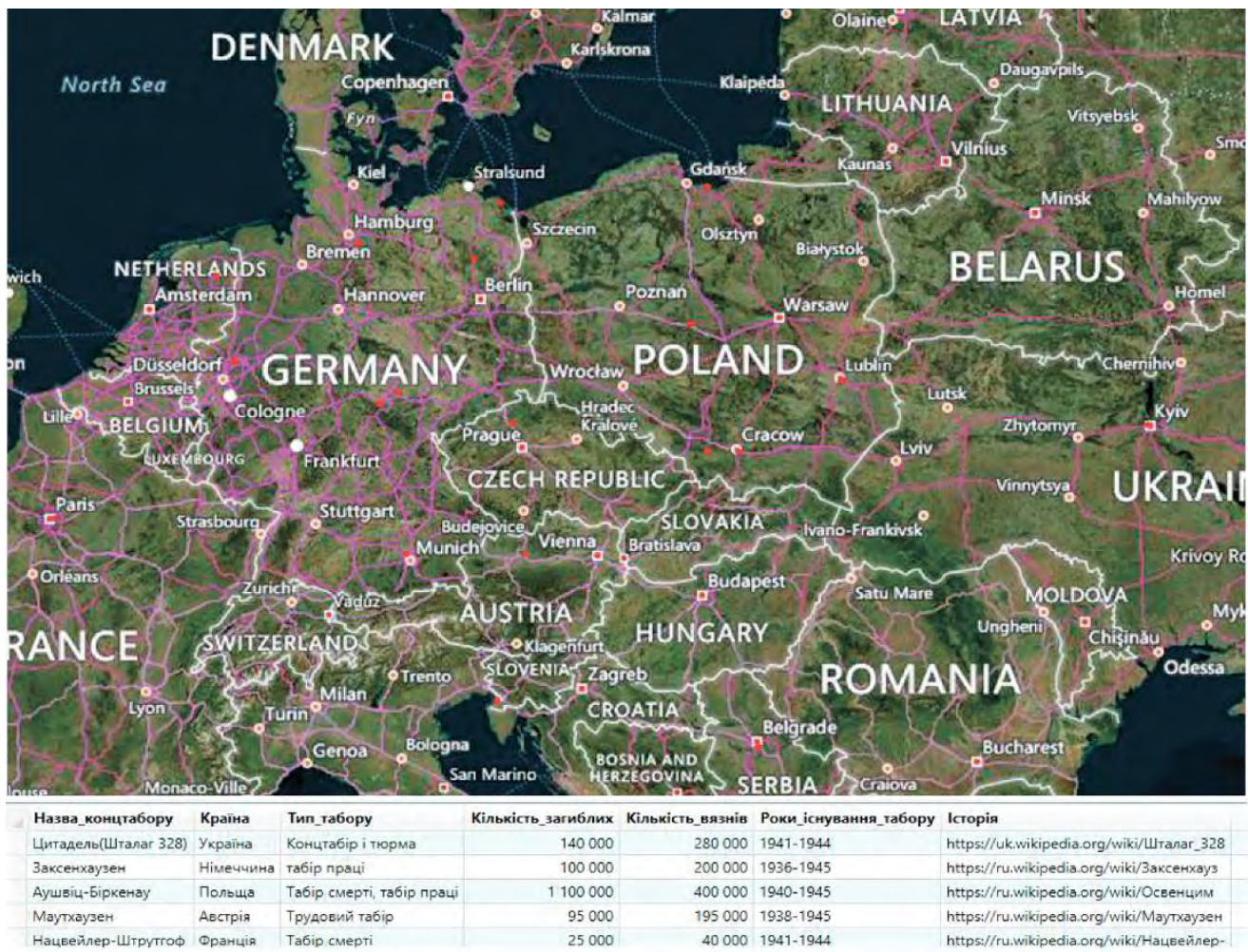

Рис. 3. Фрагмент вікон карти та атрибутивних даних створеної ГІС

\section{Результати}

У результаті реалізації поставленої мети ми отримали геоінформаційну систему із 83 об'єктами концентраційних таборів нацистської Німеччини часів Другої світової війни. Полігональні об'єкти територій таборів позначено червоним кольором із червоним штрихом. Після натискання на об'єкт інформаційною кнопкою з'являється вікно з інформацією про об'єкт згідно із спроєктованою структурою бази даних, а у разі простого натискання на полігоні кнопкою миші підвантажується вебсторінка 3 інформацією про табір iз глобальної мережі. На рис. 4 та 5 наведено приклади роботи ГІС. На рис. 4 подано приклад відображення найвідомішого жахіттями i масовими вбивствами табору смерті Аушвіц-Біркенау, розміщеного поблизу Кракова у Польщі, на рис. 5 - відображення табору праці Заксенгаузен, розташованого в містечку Оранієнбург поблизу Берліна в Німеччині. У цьому таборі утримували таких відомих в'язнів, як Яків Сталін (і стратили там) та Степан Бандера. 


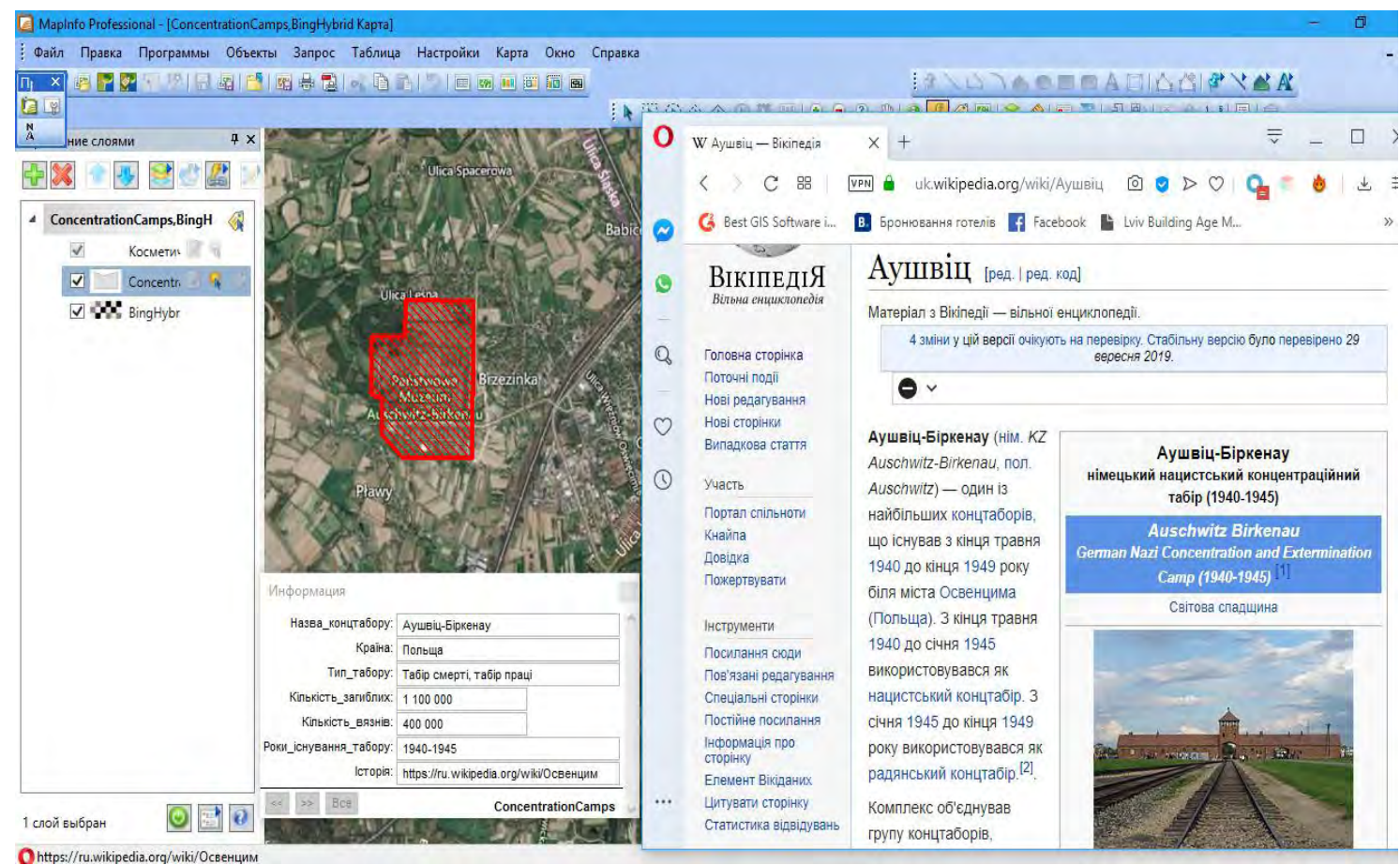

Рис. 4. Відображення з ГІС табору смерті Аушвіц-Біркенау (Польща)

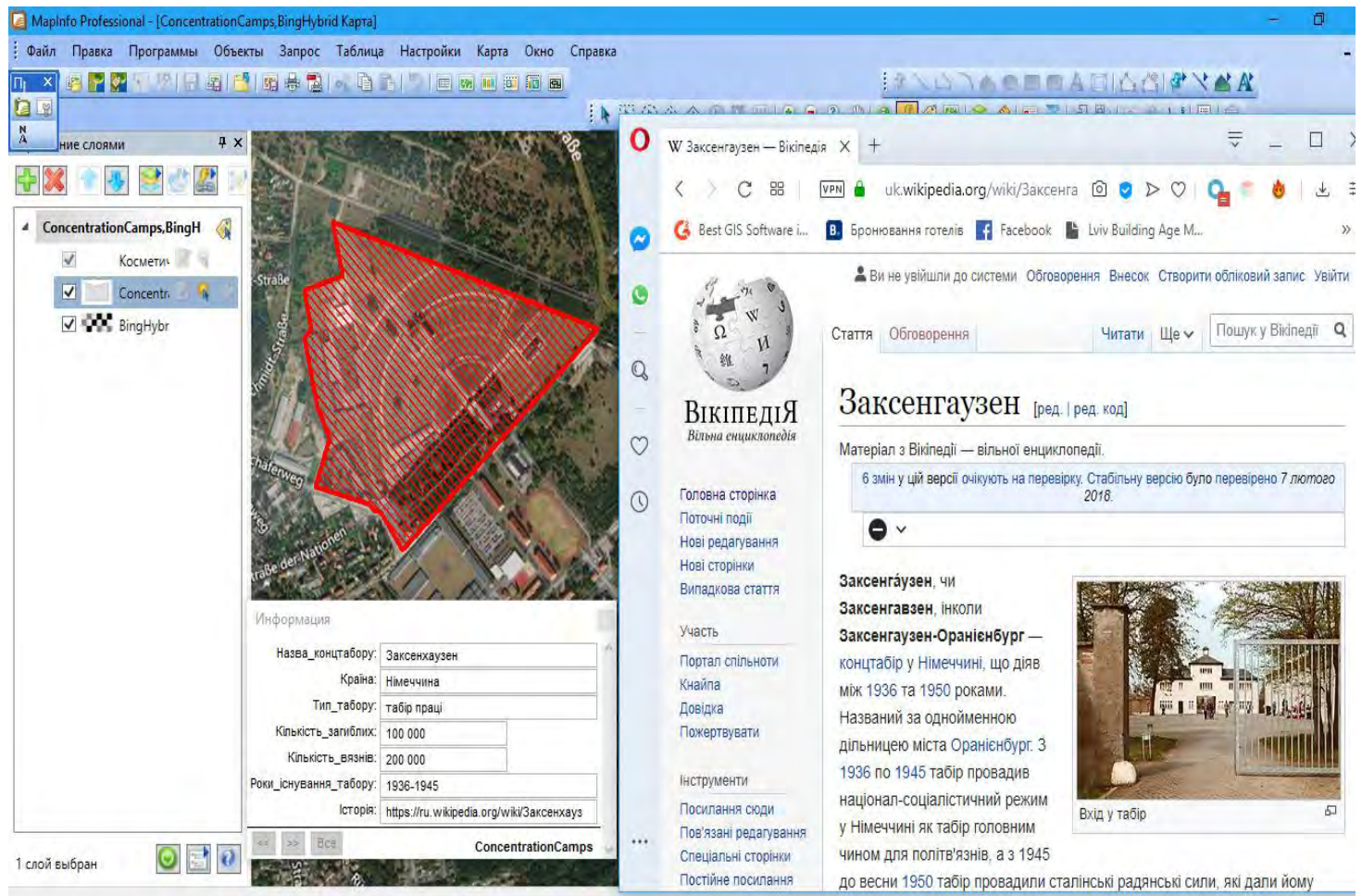

Рис. 5. Відображення з ГІС табору праці Заксенгаузен (Німеччина)

\section{Практична значущість}

Отриманою ГІС нацистських концентраційних таборів часів Другої світової війни можуть користуватись щонайменше спеціалісти, які займаються діяльністю історичного спрямування, та відділи охорони культурної спадщини України. Ї̈̈ можна доповнити за потреби іншими об'єктами, адже дослідженнями охоплено лише 83 найвідоміші табори, а їх було 1634.

\section{Висновки}

У результаті виконання поставленого завдання створено геоінформаційну систему, що містить 83 найвідоміші нацистські концентраційні табори часів Другої світової війни, серед яких:

- 24 трудові табори;

- 19 таборів смерті;

- 22 концентраційні табори; 
- 16 пересильних таборів;

- два гетто.

Створена ГІС містить графічні об'єкти полігонального типу меж таборів, найнаближеніші до реальних, а також таблицю атрибутивних даних із вичерпною інформацією про кожен табір.

Звісно, відомих таборів значно більше ніж 83, але про них недостатньо інформації. ГІС буде доповнено за можливості новими об'єктами, але це завдання ще не одного року роботи.

\section{Лiтература}

Гришин Е. С. (2017). Технологии и методика применения пространственно-временного анализа в специально исторических ГИС-проектах. Историческая информатика, № 2, С. 74-84. DOI: 10.7256/2585-7797.2017.2.23295

[Електронний ресурс]. Режим доступу: https://www. jewishvirtuallibrary.org/full-listing-of-concentrationcamps

[Електронний pecypc]. Режим доступу: http:// territoryterror.org.ua/uk/projects/prisons/nazi/

[Електронний ресурс]. Режим доступу: https://www. arcgis.com/home/item.html?id=eb6a158647ec48be 8 fe3e628f95dddbc

[Електронний ресурс]. Режим доступу: https://web. stanford.edu/group/spatialhistory/cgi-bin/site/ viz.php?id=379

Bol P., Ge J. (2005). China Historical GIS Historical Geography. Vol. 33.
Boonstra O. (1994). Mapping the Netherlands, 1830-1994. The Use of NLKAART // Coordinates for Historical Maps. St. Katharinen.

China Historical GIS

[Electronic resource]. URL: http://www.fas.harvard.edu/ chgis/ (access date: 18.02.2016).

De Belgische Samenleving in Historische Tellingen [Electronic resource]. URL: http://cartogis.ugent. be/lokstat/ (access date: 18.02.2016).

Great Britain Historical Geographical Information System (GBHGIS). [Electronic resource]. URL: http:// www.port.ac.uk/research/gbhgis/abouttheproject (access date: 18.02.2016).

Gregory I. N., Southall H. R. (2005). Putting the Past in Its Place: the Great Britain Historical GIS. Innovations in GIS. Selected Papers from the Fifth National Conference on GIS Research UK (GISRUK).

HisGIS Netherlands [Electronic resource]. URL: http://www. hisgis.nl/ (access date: 28.02.2016).

Kunz A., Boehler W. (2005). HGIS Germany: An Information System on German States and Territories from 1820 to 1914. Historical Geography, Vol. 33.

National Historical Geographic Information System (NHGIS) [Electronic resource]. URL: https://www. nhgis.org/ (access date: 18.02.2016)

Schreven L., Boonstra O., Doorn P. (2005). Towards a Historical Geography Information System for the Netherlands (HGIN). Historical Geography, Vol. 33.

\title{
B. CHETVERIKOV, M. PROTSYK
}

Department of Photogrammetry and Geoinformatics, Lviv Polytechnic National University, 12, S. Bandery str, Lviv, 79013, Ukraine, +38 (063) 1671585, e-mail: chetverikov@email.ua

\section{METHODS OF CREATION OF GIS CONCENTRATION CAMPS OF NAZI PERIOD 1941-1944}

\begin{abstract}
Aim. The purpose of robotics and the methodology of stem geoinformation systems and the extension of national tourism borders in Europe in 1941-1944. Global social policy and social information are designed: military call-up, local lore, typical camp, hour-long training, public association of people, short life. Method. The most problematic issues are the development of archival schemes and plantations of the camp. The checkpoint passed the geometry and "went" to the service Bing, Gabris (UK), Bing-space and Bing-pictures, supposedly quizzes for GIS. In order that I could find the necessary schemes and plan the intersessional transmission. For decisive action, off-season visas for historical heritage in the world (cloud architectural complexes in Ashvis), as well as for archival descriptions of mothers. Movement of privacy before judge of stem and floor schools to graphic boundaries. The database of polar and numeric types was seven columns. The first world story about the named, comprehensive and scientific life of people passes through all peoples and students. Lastly, with a brief historical content with satisfaction about progress, I think we have all the possibilities of a web scholarship for the whole country, characterized by the situation in the country, outside the country. Results. As a result of early completion of 83 semi-annual activities in a wide range between 15 regions, which can be as close to reality as possible. Until the database is provided, I will have many opportunities for development, which will be related to global problems related to the global network. Scientific novelty. It has been vectorized and programmed that technological
\end{abstract}


schemes have been prepared for participation in 43 major events and planned over the last two years, at the same time in the last years prior to cartographic education. Practical novelty. Otmania HICIBiSiKiPiSaKaOvtsilvinsk camp of the Second World War can, therefore, be baptized by specialists, supposedly in all-Ukrainian countries and in the country cultural and educational structures. Dana Gio can do his best to take part in the early rises for 83 people who were in 1634 .

Key words: concentration camp; historical GIS; classification of camps; online cartographic resource; attribute database.

Hryshyn E. S. (2017). Tekhnolohyy y metodyka $\begin{aligned} & \text { References } \\ & \text { prymenenyia prostranstvenno-vremennoho analyza v spetsyalno }\end{aligned}$ ystorycheskykh GIS-proektakh. Ystorycheskaia ynformatyka, No. 2, S. 74-84. DOI: 10.7256/25857797.2017.2.23295

[Elektronnyi resurs]. Rezhym dostupu: https://www.jewishvirtuallibrary.org/full-listing-of-concentration-camps

[Elektronnyi resurs]. Rezhym dostupu: http://territoryterror.org.ua/uk/projects/prisons/nazi/

[Elektronnyi resurs]. Rezhym dostupu:: https://www.arcgis.com/home/item.html?id=eb6a158647ec48 be8fe3e628f95dddbc

[Elektronnyi resurs]. Rezhym dostupu: https://web.stanford.edu/group/spatialhistory/cgi-bin/site/viz.php?id=379

Bol P., Ge J. (2005). China Historical GIS Historical Geography. Vol. 33.

Boonstra O. (1994). Mapping the Netherlands, 1830-1994. The Use of NLKAART. Coordinates for Historical Maps. St. Katharinen.

China Historical GIS [Electronic resource]. URL: http://www.fas.harvard.edu/ chgis/ (access date: 18.02.2016).

De Belgische Samenleving in Historische Tellingen [Electronic resource]. URL: http://cartogis.ugent.be/lokstat/ (access date: 18.02.2016).

Great Britain Historical Geographical Information System (GBHGIS) [Electronic resource]. URL: http:// www.port.ac.uk/research/gbhgis/abouttheproject (access date: 18.02.2016).

Gregory I. N., Southall H. R. (2005). Putting the Past in Its Place: the Great Britain Historical GIS. Innovations in GIS: Selected Papers from the Fifth National Conference on GIS Research UK (GISRUK).

HisGIS Netherlands [Electronic resource]. URL: http://www.hisgis.nl/ (access date: 28.02.2016).

Kunz A., Boehler W. (2005). HGIS Germany: An Information System on German States and Territories from 1820 to 1914. Historical Geography, Vol. 33.

National Historical Geographic Information System (NHGIS) [Electronic resource]. URL: https://www. nhgis.org/ (access date: 18.02.2016)

Schreven L., Boonstra O., Doorn P. (2005). Towards a Historical Geography Information System for the Netherlands (HGIN). Historical Geography, Vol. 33.

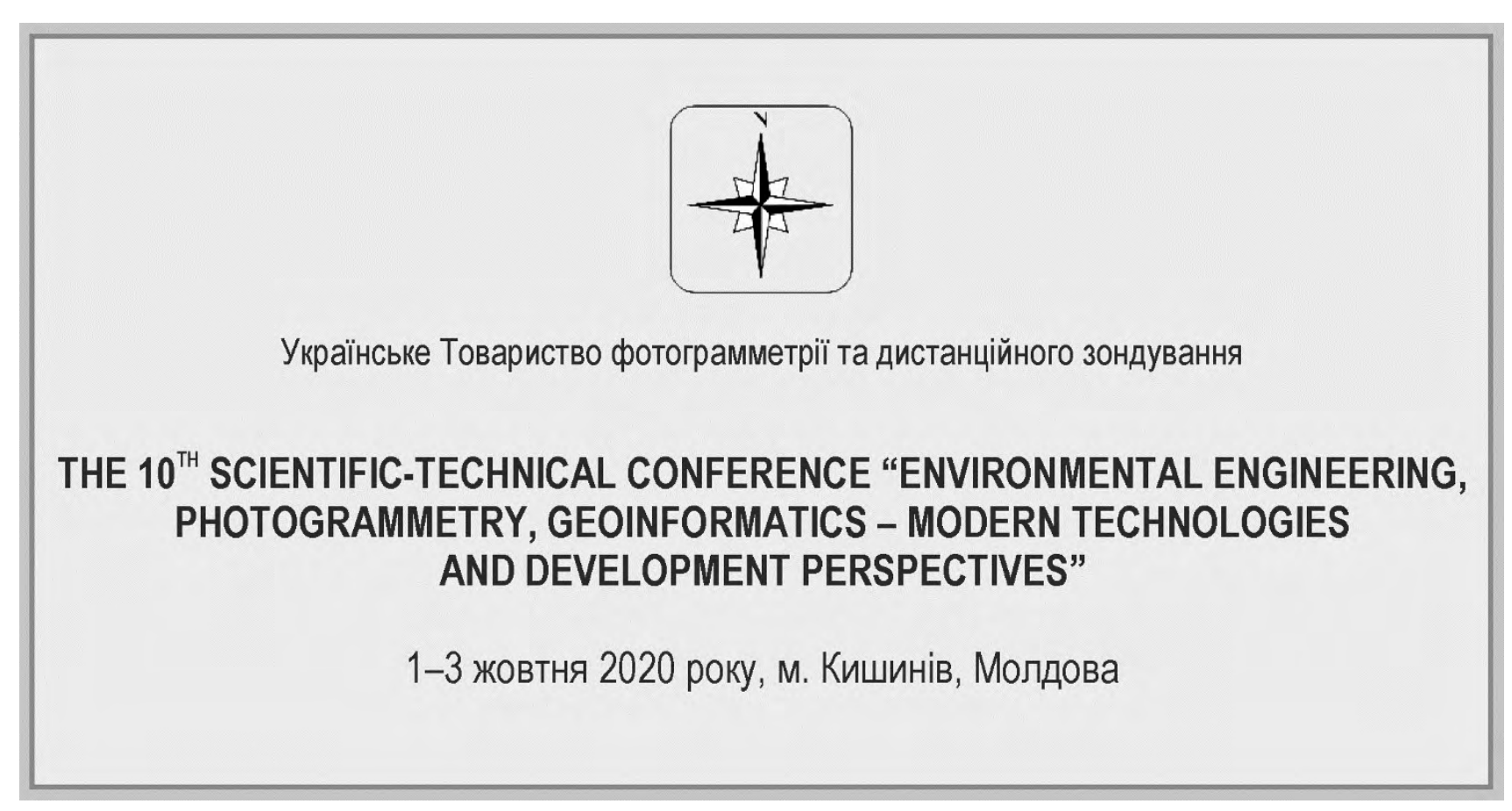

